\title{
RIMBAUD I HISTORIA PRZESTRZENNA
}

\section{KRISTIN ROSS}

PRZELOŻYLI: MiCHA£ POSPISZYL, BARTOSZ WÓJCIK

\begin{abstract}
Abstrakt: Artykuł stanowi zmodyfikowany fragment książki Kristin Ross poświęconej Komunie Paryskiej i Rimbaudowi. Autorka rozwija w nim trzy równoległe opowieści o konfliktach organizujących ówczesną literaturę, politykę i rozwijająca się pod koniec XIX wieku naukową geografię. Choć realizowany różnymi metodami, cel tych walk miałby być jednakowy i dotyczyć sposobu konstruowania przestrzeni. Jak przekonuje bowiem Ross, ideologiczne pojęcie przestrzeni (zgodnie z którym biernie oczekuje ona na podbój) zostaje wypracowane wspólnymi siłami przez antykomunardzkich polityków, elitarystycznych poetów parnasistowskich oraz ojców francuskiej akademickiej geografii. Rimbaud zaś (wespół z takimi radykałami jak Vermersch i Reclus) szkicował w swoich pracach taka koncepcje przestrzeni, w której nie będzie już miejsca na podbój, hierarchię czy charakterystyczne dla kapitalistycznego kolonializmu całkowite ujednolicenie rzeczywistości.
\end{abstract}

Słowa kluczowe: geografia polityczna, Komuna Paryska, anarchizm, poezja, kolonializm 
Rimbaud, jak się zdaje, był przedmiotem dyskusji Bertolta Brechta z Walterem Benjaminem. Ten drugi wspomina w swoich dziennikach, jak jego przyjaciel zastanawiał się nad Rimbaudem, widząc w nim najbliższego sobie poetę:

Uważa, że również Marks i Lenin - gdyby czytali wiersze Rimbauda - poczuliby wielki ruch dziejowy, który znajduje w nim wyraz. Dostrzegliby z pewnością że nie opisuje się tu ekscentrycznego spaceru poety, lecz ucieczkę, włóczęgę człowieka, który nie wytrzymuje zamknięcia w obrębie swojej klasy, kiedy ta klasa w imię merkantylnych interesów rozpoczyna - wraz z wojną krymska, z awanturą meksykańską - eksploatację egzotycznych rejonów ziemi (Benjamin 2006, 306).

Wyrażenie Brechta o „spacerach ekscentrycznego poety” było zręcznym podsumowaniem i zarazem odrzuceniem różnych mitycznych interpretacji Rimbauda jako poète mandit albo enfant terrible. Zamiast tego Brecht zachwyca się Statkiem pijanym jako narracją historyczna, a w szczególności jako wierszem, który zawiera w sobie czy też oddaje moment przejścia od kapitalizmu rynkowego do sytemu o zasięgu światowym - całej imperialistycznej gorączki końca XIX stulecia. Czyż doniosłość interpretacji Brechta nie leży w podkreśleniu związku elementów tak rzadko łączonych w krytyce literackiej czy teoriach politycznych, a mianowicie poezji i polityki, a $z$ drugiej strony historii i przestrzeni? Brecht uznając narracyjna, diachroniczna siłę wiersza Rimbauda, skupia się zarazem na ukazaniu rozwoju historycznego w kategoriach zmasowanej, synchronicznej ekspansji czy też ruchu przestrzennego: tego, jak późnodziewiętnastowieczna Europa konstruuje przestrzeń jako przestrzeń kolonialna. W ujęciu Brechta czas i przestrzeń nie są już tam, gdzie być powinny; historia stała się przestrzenna, a poezja - rozumiana jako unikalny, nieuchwytny, wyjątkowy moment - zaczęła snuć opowieści.

Późna poezja Rimbauda wyróżnia się ogromem pojęć geograficznych i nazw własnych: bieguny i strefy klimatyczne, kraje, kontynenty i miasta tworza rodzaj kartografii ruchu społecznego ujętego w terminy geograficzne. Zgodnie z sugestią Fredrica Jamesona możemy przeprowadzić bardzo wyraźny podział między erotyczną mikrogeografią czy mniej lub bardziej osobistymi zainteresowaniami wczesnego Rimbauda - jak pocałunek, który wędruje po kobiecym ciele w Wymarzonym na zime - a globalna, planetarna przestrzenia w pracach późniejszych (Jameson 1984). Przepastna geografia zbiorowych przemieszczeń, ruchów ludności i migracji dominuje w późnych, głównie, choć nie wyłącznie, prozatorskich tekstach. Błędem byłoby jednak sądzić, że w wypadku Rimbauda zwrócenie się ku prozie pokrywa się z zastạpieniem tematów osobistych, subiektywnych wątkami bezosobowymi, politycznymi. Spojrzenie geopolityczne jest u Rimbauda widoczne już w najwcześniejszych 
wierszach takich jak „Ce qu'on dit au Poete propos de fleurs” (Co mówia poetom na temat kwiatón).

Ten długi wiersz został odebrany jako parodia i manifest sprzeciwu wobec pewnej dominującej odmiany estetyzmu i retorycznych sztuczek stosowanych przez parnasistów. To właśnie tym poetom - między innymi Theodore'owi de Banville’owi, który jest adresatem wiersza, Mallarmému, Catulle’owi Mendès'owi i Leconte’owi de Lisle’a - Rimbaud, który właśnie przybył do Paryża, próbował zaimponować, a zarazem się od nich odciać. Problem z parnasistami, wyjaśnia poeta zaraz na początku swojego wiersza, to ich nadmierna dbałość o mimesis - podległość spojrzeniu:

De vos forêts et de vos prés,

Ô très paisibles photographes!

La Flore est diverse à peu près

Comme des bouchons de carafes!

Toujours les végétaux Français,

Hargneux, phtisiques, ridicules,

Où le ventre des chiens bassets

Navigue en paix, aux crépuscules

O, swojskich gajów i żyta

Beznamiętne fotografy!

Flora bywa rozmaita,

Tak jak korki od karafy!

Wciąż ta roślinność francuska,

Śmieszna, gruźlicza swarliwa.

Gdzie brzuch jamnika się pluska.

I w zmrok cichutko odpływa (Rimbaud 1993, 101).

Czy to uwięzieni w opisach flory bezpośrednich przedmieść Paryża, czy „wolni” jak Leconte de Lisle, wykpiony w dalszej części jako rodzaj Wielkiego Białego Lowcy -

Ô blanc Chasseur, qui cours sans bas

À travers le Pâtis panique,

Ne peux-tu pas, ne dois-tu pas

Connaître un peu ta botanique? 
[Biały] Tropicielu, co na przyboś

Obiegasz jurne pastwiska

O, byłoby lepiej, gdybyś

Botanikę śledził z bliska (Rimbaud 1993, 103).

- czy swobodnie przemieszczający się po egzotycznych lądach, w panicznym poszukiwaniu jak Chateaubriand i cały szereg zachodnich pisarzy przed i po nim - świeżych surowców, by ożywić nimi swoje pisanie, poeci owi obarczeni są winą „pejzażyzmu” (landscapism)1: opisują oni to, co widzą. Rimbaud nie jest osamotniony w wysuwaniu tego rodzaju oskarżeń. Przyszły komunard Eugène Vermersch, którego londyńskie mieszkanie w 1872 roku posłuży za schronienie Rimbaudowi i Paulowi Verlaine’owi, równie szybko dostrzega związek między parnasistowską fascynacją egzotyzmem a elitarystyczna postawą artystyczną i towarzyszącym jej rasizmem. W napisanym we wczesnych latach siedemdziesiątych XIX wieku Les Hommes du jour, satyrycznym cyklu złożonym z krótkich sylwetek liczących się w społeczeństwie paryskim mężczyzn i kobiet, Vermersch - tam, gdzie zwraca się do parnasisty i przyszłego antykomunarda Catulle'a Mendès’a - przybiera ton podobny do Rimbauda:

Zbyt wiele, zbyt wiele asoków, Monsieur Mendès. Co to wszystko może dla nas znaczyć te Bhandiras, Ganges, Vacu, devas, Mangu, Thandra Star, Maharchis, Cudras, Malicas? Czy to możliwe, że piszesz tylko dla swoich kilkunastu przyjaciół, którzy wyciagają się na krzesłach podczas twoich spotkań i mdleją, słuchając twoich wierszy; dla młodego Chińczyka, który chodzi sześć kroków za toba kiedy ty raczysz pokazać się ludziom? (Vermersch 187?, 11)

Asoka, najwyraźniej rodzaj indyjskiego drzewa, znajduje się w tytule parnasistowskiego wiersza Louisa Ménarda z 1855 roku; dla Vermerscha i Rimbauda ta tajemnicza roślina stała się synekdochą prac napisanych przez tych, którzy aspirują do bycia „bon Parnassian” (o co skądinąd Rimbaud żartobliwe oskarża Verlaine’a). Asoka pojawia się w kolejnych zwrotkach Co mówia poetom:

L'Ode Açoka cadre avec la

Strophe en fenêtre de lorette;

Et de lourds papillons d'éclat

Fientent sur la Pâquerette. (...)

1 Autorka tworząc neologizm landscapism, zawiera w nim dwa znaczenia: oddany w naszym przekładzie pejzażyzm, ale także nieobecny w nim eskapizm (escapism) (przyp. tłum.). 
Oui, vos bavures de pipeaux

Font de précieuses glucoses!

- Tas d'œufs frits dans de vieux chapeaux,

Lys, Açokas, Lilas et Roses!

Oda asoki przemile

Wdzięczy się w oknie kokotki

I ciężkie, pyszne motyle

Pstrzą punkcikami stokrotki (...)

Ze szpar twej dudki, biedaku,

Ciekną lepiące soki!

- Jajecznica w szapoklaku

Lilie, róże, bzy, asoki (Rimbaud 1993, 101)

Ani Mendès, ani Leconte nie protestowaliby przeciw oskarżeniom o „pejzażyzm”. Oddając głos temu, co miało się stać dominujacca postawą awangardy w XIX wieku, Leconte de Lisle zdecydowanie umieszcza „poetyckość” po stronie tego, co społecznie nieistotne: „Dla każdego, kto pisze wierszem lub proza, najważniejszym zadaniem powinno być ukazanie malowniczości rzeczy” (de Lisle 1978, 477). Dla de Lisle’a i parnasistów archaiczna, egzotyczna lub podmiejska malowniczość miała automatycznie przynieść to, co potrzebne, by wynagrodzić krzywdę światu, który - w związku z naukowym i technologicznym postępem - stał się prozaiczny.

Pejzażyzm nie ograniczał się do dyskusji czysto estetycznych; prawdziwa nauka o krajobrazie, nauka o obiektowej przestrzeni par excellence, akademicka geografia, powstaje w tej samej epoce co parnasizm. Rodzi się ona w latach siedemdziesiątych XIX wieku; to wówczas geografia zostaje zinstytucjonalizowana we Francji jako dziedzina akademicka. W ciagu tej dekady zaczyna się kształtować niesłychanie wpływowa francuska szkoła geografii. Ma to związek z takimi postaciami jak Emil Levasseur, wielki inicjator, który ukazał konieczność nauczania geografii, Luodovic Drapeyron, założyciel Revue de géographie oraz, najważniejszy, Vidal de la Blache, którego później Lucien Febvre i inni wiodący myśliciele szkoły Annales ${ }^{2}$ wynieśli na piedestał jako „ojca francuskiej geografii”. Vidaliański model

\footnotetext{
2 W ostatnim czasie ukazało się kilka bardzo wartościowych analiz i przewodników poświęconych historii francuskiej akademickiej geografii. Moja rekonstrukcja bazuje na tych pracach, zwłaszcza na: Koninck (1984) i Lacoste (1982). Korzystałam także z artykułów publikowanych przez ostatnie dziesięć lat przez Béatrice
} 
aż do lat pięćdziesiątych XX wieku będzie dominujący w obrębie studiów geograficznych. Sięgnięcie przez Febvre’a do twórczości Vidala de la Blache’a nie jest zaskakujące. Historycy szkoły Annales ustanowili w latach dwudziestych i trzydziestych model historiografii, który położy zasadniczy nacisk na elementy najczęściej uważane za geograficzne lub przestrzenne: klimat, demografię, niezmienną strukturę życia wiejskiego związaną z koncepcją czasu jako longue duree ${ }^{3}$. Francuska geografia narodziła się w latach siedemdziesiątych XIX wieku jako nieślubne dziecko dyscyplinarnej historii: Levasseur, Drapeyron i Vidal byli z wykształcenia historykami, dopiero po klęsce Francji w 1870 roku ich zainteresowania zwróciły się ku problemom geograficznym. Opisując po latach swoja przemianę, Vidal przypisze zasadniczą rolę podróżom odbytym i upamiętnionym przez ówczesnych parnasistów. Tym, co przywiodło go do geografii, pisał, były częste wyprawy do Egiptu, Grecji, Azji Mniejszej, do których jako młody człowiek jeździł odkrywać starożytne ruiny.

Vidal dostarczył klasycznej francuskiej geografii zarówno definicji, jak i metody. Definicja była zwięzła i trwała: „Geografia to nauka o krajobrazie”. Vidaliańska geografia czerpała swój model z taksonomicznej utopii nauk przyrodniczych, zdecydowanie zwracając się w kierunku opisów: geograf miał przede wszystkim odnajdywać się podczas konfrontacji z krajobrazem jako zauważalnym, widocznym aspektem przestrzeni. Gdy Vidal pisał pracę, która miała okazać się fundamentalnym tekstem francuskiej geografii, nazwał ją Tableau de la geographie de la France. Tytuł ujawnił nie tylko zawartość książki - a więc wykaz typowych krajobrazów Francji - ale także pozycje jej autora: geografa jako pejzażysty.

Metodę, której dostarczył Vidal i która przyniosła sławę szkole francuskiej, można podsumować w następujący sposób: opis geograficzny każdego kraju polega na przedstawieniu i opisaniu regionów wchodzących w jego skład. Przestrzeń zostaje zatem podzielona na regiony, które istnieją jako odrębne „indywidualności” czy „osobowości”. Zadaniem geografa jest szczegółowe zbadanie fizjonomii regionu i pokazanie, jak jego cechy wynikaja $z$ harmonijnej $i$ nieustannej interakcji pomiędzy warunkami naturalnymi a dziedzictwem historycznym. Minęło wiele pokoleń, zanim ludzie zauważyli, że regiony Vidala nie były naturalnymi „faktami”, że na przykład Brytania nie była całością wydzielona przez Boga.

Jakie są konsekwencje definicji i metodologii Vidala? Po pierwsze, definicja, która przedmiotem badań czyni „krajobraz”, stosuje wyłącznie naoczne kryteria, a geografa określa

Giblin w czasopiśmie radykalnej francuskiej geografii Hérodote. Zob. także amerykański odpowiednik czy też „pismo siostrzane” w stosunku do Hérodote, Antipode; zwłaszcza Hudson (1977, 12-19).

${ }^{3}$ W 1922 roku Lucien Febvre napisał La Terre et I'evolution bumaine, książkę, która przedstawiała teoretyczne poglądy Vidala. Była to pierwsza epistemologiczna refleksja nad geografia i historia geografii, co podkreślał podtytuł pracy: „Wprowadzenie geograficzne do Historii”. 
interpretatorem stanów natury. Vidal definiuje krajobraz „jako to, co oko może objąć swoim spojrzeniem” lub, w innej formule, jako „część kraju, w której natura oddaje się oku, które na nią patrzy". Można powiedzieć że działają w tych definicjach - przynajmniej do pewnego stopnia - metafory seksualne, gdy mowa o tym, że „przestrzeń staje się kobieca” albo że „oddaje się” temu, kto ją ogląda. Wszystko to jest zaledwie wstępem do bardziej jawnych „penetracyjnych” metafor używanych przez późniejszych geografów/odkrywców. Tutaj chce przede wszystkim wskazać na to, jak charakterystyczna dla Vidala fetyszyzacja naocznych kryteriów ulega ironicznemu nadwątleniu. Radykalne geografki takie jak Béatrice Giblin dowodza przekonująco, że krajobrazy Vidala w rzeczywistości nie moga być widziane; jego mistrzostwo, niemal parnasistowski styl literacki maskuje fakt, że nie zajmuje się on precyzyjnie zlokalizowanymi krajobrazami, które można poddać obserwacji ale raczej krajobrazem typowym, który Vidal konstruuje za pomocą wtórnych i abstrakcyjnych konceptualizacji (Giblin 1978, 74-89; Lacoste 1979, 68-81). To właśnie uruchomienie tego rodzaju syntetycznych i wtórnych klisz w poezji parnasistowskiej wyśmiewa Rimbaud:

Tu ferais succéder, je crains,

Aux Grillons roux les Cantharides,

L'or des Rios au bleu des Rhins,

Bref, aux Norwèges les Florides

Wnet oddać miałbyś ochotę

Gzy rude za kantarydy,

Ren siny za Rio złote

A Norwegie za Florydy (Rimbaud 1993, 103)

Występujące w liczbie mnogiej geograficzne nazwy własne (co słychać, gdzie macie swoje Florydy, wasze Norwegie) trywializuja parnasistowską praktykę jako odwoływanie się do oderwanych, urzeczowionych elementów: Floryda nie jest już tutaj miejscem pod każdym względem wyjątkowym, ale staje się mieszanką egzotycznych stereotypów, zasłyszanych cytatów i rzekomych odniesień botanicznych. Poprzez prostą zmianę ptaka, owada, koloru, PRESTO! Jesteśmy w Norwegii.

Zarówno w parnasistowskim, jak i Vidaliańskim krajobrazie przestrzeń występuje jako naturalny desygnat. W geografii tego autora, która powstała przecież pod koniec XIX wieku, uderza niemal całkowite wymazanie bieżących wydarzeń: rewolucji przemysłowej, kolonializmu, głodu czy urbanizacji. Miasta w bardzo niewielkim stopniu należą do tej geografii. Metodologia regionalizmu wytwarza z kolei geografię trwałości: to, co na wsi, 
od bardzo dawna jest na swoim miejscu. Tego rodzaju rozumienie przestrzeni służy ukryciu społecznych i ekonomicznych sprzeczności, których głównym obszarem jest ta przestrzeń. Samo pojęcie „regionu”, tak jak konstruuje je Vidal, oznacza jednorodne, zhomogenizowane społeczeństwo pojednane ze swoim naturalnym środowiskiem i zjednoczone wokół jednej zbiorowej woli. W rzeczywistości „zhumanizowane krajobrazy” pojawiają się dość rzadko w dziewiętnastowiecznej geografii akademickiej; jeśli ludzie w ogóle w nich występują, to wyłącznie jako element wzmacniający naturalną harmonię danego regionu: tubylec, chłop staje się częścią krajobrazu, dekoracją.

Gdy tylko ewolucja społeczeństwa kapitalistycznego stworzyła ogromne zapotrzebowanie na naukowa geografię, zaczęto poszukiwać profesjonalnych geografów. Geografia vidaliańska miała zatem odegrać istotną rolę w naturalizacji fundamentów ideologii narodowej. Wyjątkowy status przestrzeni jako obiektu naturalnego - co stało się jeszcze bardziej oczywiste w kolejnych dekadach - doskonale odpowiadał potrzebom zachodniego kolonializmu. Zachodni, chrześcijański kolonializm wymagał określonej interpretacji przestrzeni, której dostarczyć miała mu vidaliańska akademicka geografia - przestrzeni naturalnej, to znaczy, ahistorycznej, a także takiej, w której wszelka odmienność pozostaje nieobecna. Swój wkład w konstruowanie przestrzeni jako przestrzeni kolonialnej miało co może być zaskakujące - także Saussurowskie językoznawstwo (de Saussure napisał swoją pierwszą ważną pracę w latach siedemdziesiątych XIX wieku). Aby zrozumieć, jak Saussurowski znak odnosi się do podwójnie zdeterminowanego (pozajęzykowo, a nade wszystko naturalnie) desygnatu przestrzennego, być może wystarczy przypomnieć kanoniczny przykład, za pomocą którego uczono nas jego koncepcji znaku. Kiedy wypowiadam słowo „drzewo” (obraz akustyczny, element znaczqcy); przychodzi nam do głowy pojęcie „drzewa” (w tym momencie na tablicy rysuje się drzewo), ale to nie jest prawdzịwe drzewo, które jest tam, na zewnątrz (pozajęzykowe, przestrzenne i naturalne) ${ }^{4}$.

De Saussure twierdził, że w jego definicji znaku rola denotacji - relacji znaku do desygnatu - jest marginalna. W konsekwencji rola ta była nieistotna i bardzo niejasna także w jego językoznawstwie. Hegemonia de Saussure'a we francuskim literaturoznawstwie ostatnich trzydziestu lat była dominacja jezzykoznawstwa skoncentrowanego na problemie znaczenia, rozumianego jako relacja znaczącego (signifiant) i znaczonego (signifiè), przesuwająca na dalszy plan kwestię odniesienia do rzeczywistości. De Saussure i jego zwolennicy przyczynili się do „uprzestrzennienia” języka, był to jednak szczególny rodzaj

$4 \mathrm{~W}$ kontekście analizy syjonizmu Uri Eisensweig wykazywał istnienie związku między Saussurowskim językoznawstwem a zachodnią konstrukcją przestrzeni kolonialnej (zob. Eisensweig 1980). Argumentacja Eisensweiga daje się zastosować nie tylko w odniesieniu do syjonizmu, ale również w kontekście dziewiętnastowiecznego imperializmu. 
przestrzenności: stanowiła ona konsekwencję rygorystycznego oddzielenia znaczącego od znaczonego oraz przyznania temu pierwszemu zasadniczej roli w tym, co nazywamy „grą" językowa. Można ją zatem zdefiniować jako oparty wyłącznie na różnicach system relacji, w którym każdy element określony jest przez miejsce zajmowane w sieci poziomych i pionowych relacji, w jakie wchodzi on z elementami sąsiadującymi. Dobrze znamy tę Saussurowską przestrzenność języka, która nie przystaje ani do przestrzeni geometrycznej, ani - co ważniejsze - do przestrzeni żywego doświadczenia, codziennego życia. Jeśli jednak wrócimy do wiersza Rimbauda, to możemy moim zdaniem doświadczyć innego rodzaju przestrzenności. Językoznawstwo tego poety skupia się bowiem w większym stopniu na problemie referencji, odniesienia do rzeczywistości - „jedwabiu mórz i kwiatów arktycznych (one nie istnieja)” (Rimbaud 1993, 239); „Barbarzyńcy” - denotacji, niźli na problemie znaczenia. Na samy środku parnasistowskiej sceny Rimbaud niespodziewanie umieszcza problem desygnatu:

\author{
Là!... Comme si les Acajous \\ Ne servaient, même en nos Guyanes, \\ Qu'aux cascades des sapajous, \\ Au lourd délire des lianes!
}

To tak, jakby las mahonii

Po to rósł w gąszczach Gujany

By małpki pięły się po nich

Lub w ciężkiej malignie liany! (Rimbaud 1993, 103)

Późniejsza poezja Rimbauda, jak już wspomniałam, charakteryzuje się upowszechnieniem nazw geograficznych, ale sposób, w jaki używa on geografii, jest zupełnie inny, a nawet krytyczny wobec - przeważającego w dziewiętnastowiecznej literaturze francuskiej orientalnego czy egzotycznego zawłaszczania nazw miejscowych. W cytowanym fragmencie, dla przykładu, zamiast parnasistowskich Floryd czy Norwegii mamy nie tyle „Gujany”, ale „nasze Gujany”. Zaimek dzierżawczy połączony z nazwą własną stanowi przykład tego, co filozofowie języka za Russellem nazywaja „deskrypcja określona”, a więc przykład denotacji, a nie konotacji. Takie użycie deskrypcji określonej spełnia zatem funkcję referencyjną tj. funkcję sformułowania, które może zmieniać swój desygnat w związku ze zmianą czasu, nadawcy lub kontekstu - słowem, w zależności od historii. Zaimek dzierżawczy działa tutaj jako przesuwak (shifter), wskazując na szczególną społeczno- 
polityczną rzeczywistość swojego wypowiedzenia: użycia geograficznych nazw w historycznych, a nie bezczasowych okolicznościach.

Dwie rzeczy zwracaja naszą uwagę w tej strofie. Po pierwsze, zdecydowany opór Rimbauda przeciwko parnasistowskim ograniczeniom odnośnie do tego, co stanowi właściwy temat poezji. Opowiadając się za definicją poetyckości, która obejmuje tematy społecznopolityczne, praktyczne, przyziemne zainteresowania, poeta ustawia się nie tylko w opozycji do parnasistów, ale także przeciwko temu, co stanie się dominująca tendencją w większości dziewiętnasto- i dwudziestowiecznych awangard. Najlepszy przykład stanowi tu ciagła higieniczna troska Mallarmégo o ochronę prawdziwie poetyckiego języka ewokacji przed wszechobecną wulgaryzacja roznoszoną przez burżuazyjny utylitaryzm i precyzję. Co ważniejsze, „nasze Gujany” i wiele innych przykładów z uprawianej przez Rimbauda poezji zaimków wskazujących, przesuwaków, imion własnych czy „deskrypcji określonych” prowadzi nas do wielokrotnie powtarzanego problemu desygnatu, w okresie, w którym cała poezja ogłasza swoją odporność na jakiekolwiek zmiany w denotacji. Zamiast jak Mallarmé problematyzować związek znaczonego i znaczącego - co widać na przykładzie takich eksperymentów przestrzennych jak typograficzny układ słów w Græe w kości - Rimbaud koncentruje się na problemie desygnatu: stąd jego skłonność do inwektywy i sloganu, do języka będącego na granicy z działaniem. (Tutaj także ujawnia się bliskość z performatywną polityką pragnienia sytuacjonistów, Deleuze'a i Guattariego oraz innych twórców z pokolenia maja 1968). Dominująca metodologia czy filozoficzne zainteresowania zawsze generowały listę „wybranych tekstów”, które najlepiej odpowiadają przyjętemu sposobowi analizy. Teoria literatury ostatnich trzydziestu lat - od strukturalizmu do dekonstrukcji - nie jest tutaj wyjątkiem. Kanonizacja Mallarmégo i de Saussure'a kosztem Rimbauda idzie w parze z pierwszeństwem, jakie w ostatnich latach dawano epistemologii i estetyce nad myślą społeczną, a także z uświęceniem romantycznej „polityki” tekstualności (tej ludycznej kontrlogiki semantycznej destabilizacji), które cechuje dużą część francuskiej teorii, zwłaszcza tej importowanej do Ameryki.

Być może najlepszym sposobem na wyjaśnienie różnicy między Rimbaudem a kanoniczną awangarda jest zderzenie czytanego przez nas wiersza o kwiatach ze słynna uwagą Mallarmégo dotyczącą znikającego kwiatka: „Je dis: une fleur! et, hors de l'oubli où ma voix relègue aucun... se lève, idée même et suave, l'absente de tous bouquets” („mówię «kwiat» i z niepamięci, do której mój głos wtrąca wszelkie kontury, wznosi się muzycznie, jako coś innego niż znane kielichy, sama idea, urzekająca, mieszanka wszystkich bukietów”). Dyskurs poetycki „zastępuje” tutaj desygnat; słowo „kwiat” eliminuje kwiat. Język poetycki mówi o rzeczach raczej pod ich nieobecność niż w ich obecności. Jakże inaczej pisze o kwiatach Rimbaud, którego wiersz zadaje pytanie: jak pisać o kwiatach w 1870 roku bez 
pisania o fleur de lys, wraz z jego wszystkimi związkami z francuską władzą państwową i istniejącymi hierarchiami? Odpowiedź Rimbauda jest krótka: „Wyszukaj nam kwiaty krzesła” (Rimbaud 1993, 105). I jakże inna będzie taka jego strofa:

Dis, front blanc que Phébus tanna,

De combien de dollars se rente

Pedro Velasquez, Habana;

Incague la mer de Sorrente

Wyśpiewaj nam plon zebrany,

Dolary płynące renta

Do Velasqueza z Habany;

Rozmnażaj śledzie w Sorrento (Rimbaud 1993, 105)

Rimbaud używa tutaj czegoś w rodzaju wojskowego rozkazu: nie tyle „ja mówię” (w sensie „ja mówię: kwiat!”), ale „powiedz to”. Rozkaz jest tutaj przesuwakiem, wskazuje na historyczny moment i sytuację wypowiedzi, nadawcy i adresata. „Pedro Velasquez z Habany" może istnieć lub nie; liczy się tu wskazująca funkcja imienia własnego, która umożliwia skonstruowanie zestawu relacji ekonomicznych i polityczno-społecznych; oznaczonych, nie przedstawionych. U Rimbauda najmniejszą jednostką rzeczywistości nie jest słowo, pojedyncze pojęcie, ale raczej układ, proces składania lub konfigurowania elementów. Układ ten, tak jak widzieliśmy w cytowanym fragmencie, nigdy nie jest przestrzenią neutralnej wymiany, tutaj zostaje ustanowiona nie tylko różnica ekonomiczna, ale również - poprzez użycie jeszcze innego imienia: ponadczasowego, mitologicznego Febusa - różnica rasowa. W przeciwieństwie do Rimbaudowskiego „Pedro Velasqueza” parnasistowskego poetę wyraża tu synekdocha jego białej skóry, muśniętej przez słońce mitologii, przez cała zachodnią tradycję tworząca tekstualną opaleniznę.

Desygnat Rimbauda nie jest zatem ani czysto naturalny, ahistoryczny jak u de Saussure'a, ani tekstualny jak u poststrukturalistów, gdzie jest wyłącznie konstruktem naszej własnej krytycznej atmosfery. Jest to z pewnością obiekt skonstruowany, jednak w sposób, który dopuszcza zmianę historyczna. Rimbaud zasiedla swoje krajobrazy, ale robi to w taki sposób, że „Pedro Velasquez” nie staje się dodatkiem ani wystrojem. Jego rozumienie przestrzeni umożliwia mu przesunięcie na pierwszy plan stosunków społecznych: przestrzeń staje się przestrzenią społeczną, a nie pejzażem.

W tym momencie musimy wrócić do naszej teorii geografii akademickiej, aby zaznaczyć, że instytucjonalizacja „geografia krajobrazowej” i dominacja Vidala de la Blache’a 
była wynikiem znamiennego wykluczenia dzieła anarchistycznego geografa Élisée’a Reclusa. Podobnie jak u Rimbauda wyobraźnia polityczna Reclusa, jego osobista geografia naznaczona była przez aktywny udział w Komunie Paryskiej. To z tego powodu zostanie internowany do Szwajcarii (jego sława jako geografa uchroniła go od deportacji do Nowej Kaledonii), gdzie stworzył większość swoich głównych dzieł. Reclus uczestniczył w sporze, który doprowadził do rozłamu między Marksem a Bakuninem w 1872 roku, oraz bronił anarchokomunizmu w licznych artykułach, publikowanych w takich pismach jak Le Revolte czy La Liberte. Do geograficznych współpracowników Reclusa zaliczali się tacy anarchokomuniści jak Malatesta czy Kropotkin, którzy dostarczali mu informacje na temat Włoch i Rosji. W swoich pismach politycznych bronił idei społeczeństwa wywiedzionej z Komuny, idei społeczeństwa zorganizowanego od dołu do góry oraz rozwiązującego problemy biurokracji samorządnościa pracowniczą i wolnością organizacji robotniczych w stosunku do partii. Jego stałym zmartwieniem był problem państwa oraz jego stosunku do jednostki ${ }^{5}$. W 1879 roku, gdy rząd francuski ogłosił w stosunku do Reclusa oficjalną amnestię, odmówił powrotu do Francji aż do czasu, w którym amnestia zostanie zagwarantowana wszystkim Komunardom.

W przeciwieństwie do swoich rówieśników Vidala, Drapeyrona i Levasseura, Reclus został intelektualnie ukształtowany nie przez historię, lecz przez teologię. O ile dla Vidala wybór zawodu geografa był inspirowany wycieczkami po antycznych ruinach Egiptu i Grecji, o tyle dla Reclusa decydujące były jego wyprawy do Ameryki i Irlandii, podczas których uderzony został ogromem zniszczeń powodowanych wielkim głodem. To umocniło go zarówno w socjalistycznych przekonaniach, jak i w decyzji o poświęceniu się geografii.

Reclus - który jako pierwszy użył terminu „geografia społeczna” - przeciwstawił Vidalowskiej definicji geografii jako nauki o krajobrazie definicję, w której „geografia jest niczym innym jak historia w przestrzeni”. Dlatego jego analiza bierze pod uwage przestrzeń jako zróżnicowaną, ruchomą, zmieniającą się całość: „Geografia nie jest niezmienna. Każdego dnia jest ona tworzona, przetwarzana; ciagle przekształcana przez działania człowieka" (Reclus 1982, 335). Zazwyczaj Reclus unika empirycystycznego urzeczowienia

\footnotetext{
${ }^{5}$ Stąd też problematyczna relacja Reclusa z ówczesnym „oficjalnym” marksizmem. W swojej przedmowie do Le Socialisme en danger (Nieuwenhuis 1897) pisze: „Zobacz z jakim oddaniem traktowany jest Marks, na cześć którego setki tysięcy fanatyków unosi ręce do nieba, składając obietnicę religijnego przestrzegania jego doktryny! Czyż cała partia, cała armia kilkudziesięciu posłów w niemieckim parlamencie, nie interpretuje dziś doktryny marksistowskiej w dokładnie przeciwny sposób niż jej mistrz? Marks twierdził, że siły ekonomiczne określają polityczną formę społeczeństw, tymczasem jego zwolennicy popierają tę ekonomiczną siłę, od której zależy posiadanie większości w parlamencie. Podczas gdy Marks twierdził, że «aby państwo zakazało biedy, musi wpierw zakazać siebie, ponieważ źródło zła leży w jego istnieniu», to wyznawcy marksizmu skłonni są się nawzajem pozabijać, by tym państwem kierować. Jeśli myśl polityczna Marksa zwycięży, to będzie niczym religia Chrystusa, zwracająca się do swego mistrza tylko by go adorować, nie przejmując się jego ideami w praktyce" (Reclus 1897, VIII).
} 
pojęcia przestrzeni, które pojawia się, kiedy ktoś postuluje istnienie autonomicznych przestrzennych faktów, procesów albo struktur konstytuujacych przedmiot przestrzennej analizy. Przestrzeń w pracy Reclusa jest pojmowana jako wytwór społeczny - albo raczej jako zarazem wytwórca i wytwór, określający i określenie - którego nie można wyjaśnić bez uciekania się do badań nad funkcjonowaniem społeczeństwa. Reclus dzięki nieustającemu zainteresowaniu analizą relacji władzy między imperiami, państwami i ludźmi musi odrzucić Vidalowską definicje geografii jako „nauki o miejscach, a nie o ludziach”. Prowadzone przez niego badania z niezwykłą drobiazgowościa pokazują między innymi zmiany powodowane przez kolonizację autochtonicznych populacji i organizację ich przestrzeni, antycypując w ten sposób wiele współczesnych teorii nierównego rozwoju. W skrócie, wytwarza on taki rodzaj analizy, który zostanie wyparty i całkowicie zniknie w późniejszej redukcji geografii do wąskiej i wyspecjalizowanej dyscypliny.

Co mówia poetom na temat kwiatów kończy się efektowną metaforą i zaleceniem:

Voilà! C'est le Siècle d'enfer!

Et les poteaux télégraphiques

Vont orner, - lyre aux chants de fer,

Tes omoplates magnifiques!

Surtout, rime une version

Sur le mal des pommes de terre!

- Et, pour la composition

De poèmes pleins de mystère

Qu'on doive lire de Tréguier

À Paramaribo, rachète

Des Tomes de Monsieur Figuier,

- Illustrés! - chez Monsieur Hachette!

To wiek piekła! O współcześni!

Słup telegrafu radośnie

Jak lira żelaznej pieśni

Nad ramionami wyrośnie!

Bierz nade wszystko za temat

Ziemniaczane pasożyty 
- Zresztą, składając poemat,

Gdzie sens tajemny ukryty,

W Paramaribo Treguiera

Powinien czytać poeta,

Jak również tomy Figuiera

Z rycin, u Hanchette'a (Rimbaud 1993, 107-109)

W pierwszej strofie ciało poety przeszło niesamowita metamorfozę: nie jest już oddzielonym obserwatorem, „spokojnym fotografem” z początku poematu, ale zostaje bezpośrednio wciągnięte $\mathrm{w}$ zmianę $\mathrm{w}$ obrębie produkcji i reprodukcji. Jego ciało zmieniło się. Innymi słowy, celem nie jest tu jedynie zmiana „tematyczna” - podstawienie pytań ekonomicznych w miejsce estetycznych czy obrazowych. W tej złożonej cielesnej alegorii techniki to, co naturalne i to, co techniczne ściśle przynależy do siebie nawzajem, niczym we współczesnych Rimbaudowi neologizmach, takich jak „konie parowe” czy „konie mechaniczne". Rozwinięta technika wiąże się z biologicznymi, żywymi istotami i to z niej wyłoni się inna, hybrydowa, mglista formacja Whitmanowska: pieśń stali. Ciało ludzkie przenikają elementy przypominające aparaturę; podobnie, na przykład, używa się języka telegrafii do opisu systemu nerwowego w dziewiętnastowiecznych tekstach popularnonaukowych.

Te teksty popularnonaukowe sa anonsowane w ostatniej strofie „Jak również tomy Figuiera/ Z rycin, u Hachette'a”. Louis Figuier, autor między innymi The Marvels of Science, był czołowym popularyzatorem nauki w czasach Rimbauda ${ }^{6}$. Jego La terre et les mers, stale wznawiana między 1864 a 1884 rokiem, była prawdopodobnie najchętniej czytaną „popularną” publikacją z zakresu geografii w ówczesnej Francji. Figuier nie był jedyną ważną postacia publikująca w Hachette; wydawca drukowal także bardzo popularne w tamtym czasie atlasy i traktaty geograficzne Reclusa (z których korzystał przy pracy nad swoimi powieściami Juliusz Verne, także wydawany w Hachette). Rimbaud posłuchał swojej własnej rady miesiąc później i podczas pisania Statku pijanego zapożyczy wiele nie tylko od Figuiera, ale

\footnotetext{
6 Vermersch pokazuje nam satyryczny obraz „kolażowej” metody kompozycyjnej Figuiera: „La Cuisiniere bourgeoise powiada, «By udusić zająca, złap zająca». Monsieur Louis Figuier pisze: «By napisać książkę, weź inne książki». Następnie uzbraja się w gigantyczne nożyczki i wycina, z prawa i z lewa, z prac, które są naukowe i z tych, które nie są, z gazet, w których użytek robi tak z różnorakich zdarzeń, jak z felietonów; gdy już ma wystarczającą ilość tych fragmentów, to składa je w książkę. Wszystkie te kawałki i części, wzięte z trzystu autorów, następuja po sobie bez żadnego porządku, bez żadnych zapośredniczeń, bez połączeń, przeciwstawiając się jedne drugim, tworzą przedziwny arlekinowy kostium, jaki rodzice kupują swoim dzieciom na Nowy Rok, których jednak, na szczęście, dzieci nie czytaja”" (Vermersch 187?, 78).
} 
także z najbardziej libertyńskiej powieści Verne’a 20000 mil podmorskiej żeglugi czy z Praygód Artura Gordona Pyma Poego.

Historycy francuskiej polityki kolonialnej najczęściej przedstawiali wzrost francuskiego zainteresowania ekspansją kolonialna, koncentrując się na jego gwałtownym rozwoju w latach osiemdziesiatych XIX wieku. O ile nie możemy mówić o pełnoprawnym ruchu kolonialnym w latach siedemdziesiątych, to na pewno można rozpoznać istnienie w tym okresie ważkiego ruchu geograficznego ${ }^{7}$. Geografia, jak to ujął antykolonialny geograf Jean Dresch, nie rodzi się podcras tryumfu burżuazji; jej rozwój jest nieodłacznq czéśiq tego tryumfu (Jean Dresch, cyt. za: Santos 1984, 19). W następnej dekadzie po zwycięstwie Prus i stłumieniu Komuny „geograficzna gorączka” opanowała Francję. Oznaki nowego zapału do geografii pojawiły się wszędzie: nie tylko w ustanowieniu akademickiej geografii przez historyków-renegatów, Levasseura, Vidala de la Blache'a i innych, ale także w podniesieniu poziomu nauczania geografii na każdym szczeblu systemu edukacyjnego oraz w licznych narodowych i międzynarodowych kongresach, który odbywały się wówczas we Francji. Zaraz po wojnie grupy nacisku wywołały narodową kampanię na rzecz otwarcia w Paryżu Ecole Supérieure de Géographie. W połowie lat siedemdziesiątych pojawiły się pierwsze czasopisma całkowicie poświęcone geografii - L'Explorateur i Revue de géographie; francuskie towarzystwa geograficzne, które w 1881 roku jednogłośnie poparły podbicie Tunezji, przeżywały coś, czego nie da się nazwać inaczej niż astronomiczną ekspansja. Przed 1871 rokiem było tylko jedno takie towarzystwo, z siedzibą w Paryżu, zrzeszające nie więcej niż setkę członków; dziesięć lat później istniało już dwanaście nowych znaczacych towarzystw oraz wiele pomniejszych, z ponad dziewięćset pięćdziesięcioma członkami (Depping 1881, 1).

W roku 1881 belgijski geograf napisał: „Żaden kraj nie zrobił więcej dla rozwoju i popularyzacji jednej gałęzi nauki niż Francja od czasów wojny z 1870 roku" (Hermann Wagner, cyt. za: Broc 1974, 564). Ta data, 1870, i towarzyszące jej wydarzenie sa kluczowe. W powszechnym przekonaniu porażka Francji z Prusami była spowodowana przez to, że francuskie oddziały nie znały dostatecznie dobrze geografii. Kiedy w 1877 roku zaczyna wychodzić Revue de géographie, pierwszy numer uzasadnia swoje powstanie takimi uwagami: „Wszyscy pamiętamy te wadliwe mapy dostarczone naszym oficerom w 1870 roku, które zawierały ledwie opisy regionów będących teatrem działań tamtej fatalnej wojny" (Picard 1877, 1) $)^{8}$. Nic dziwnego, że autorem tych uwag był Ernest Picard, minister spraw

\footnotetext{
7 Znakomitą analizę i historię francuskich towarzystw geograficznych można znaleźć w książce Agnes Murphy, The Ideology of French Imperialism (Murphy 1948) i u Vernona McKay, w pracy „Colonialism in the French Geographical Movement 1871-1881” (McKay 1943). W swoim opisie tych towarzystw opieram się na powyższych pozycjach.

8 Wielkie poruszenie wywołał artykuł Levasseura zatytułowany „O studiach i nauczaniu geografii”, który sugerował, że problemem wcale nie były mapy: „Nie chcemy, żeby nasz kraj padł łupem obcokrajowców.
} 
wewnętrznych w rządzie Thiersa i czołowy strateg Wersalu w czasach Komuny Paryskiej. Élisée Reclus, po upływie pięciu lat od upadku Komuny wciąż przebywający na wygnaniu w Szwajcarii, z niecierpliwością oczekiwał na pierwszy numer Revue de géographie, w którym miał nadzieję opublikować część swoich prac; ku swojemu przerażeniu we wstępie do czasopisma nadział się na Picarda, czyli osławionego antykomunarda, choć przyoblekającego się w nowe szaty:

Musiałeś otrzymać Revue de géographie Drayperona. Muszę przyznać, że spodziewałem się czegoś lepszego. Ten list Picarda, który nie ma pojęcia o geografii, umieszczony w samym sercu czasopisma jak flaga powiewająca na dużym maszcie okrętu, to roszczenie, by z geografii uczynić politykę administracyjną, roszczenie niemające ostatecznie żadnego innego motywu, niż uczynienie geografii służebną wobec ambicji politycznych (Reclus 1911).

Mimo iż Reclusowska metafora czasopisma geograficznego jako okrętu państwa okazała się prorocza, z początku przynajmniej obiektywnie nic nie łączyło towarzystw geograficznych które zresztą kilka lat później opublikuja niektóre z artykułów Rimbauda wysłane z Afryki z ekspansją kolonialna. W swoich biuletynach i protokołach z zebrań stawiały one sobie wyraźnie za cel szerzenie „naukowych zainteresowań” geografią oraz wspieranie powojennej odbudowy Francji. Jednak w następnych latach towarzystwa te w coraz większym stopniu funkcjonowały jako agencje propagujące rejsy i wyprawy; pierwsze francuskie towarzystwo geografii handlowej zostało założone w 1874 roku. Drapeyron w piśmie z 1875 roku ogłosił, że „świat będzie należał do tego, kto pozna go najlepiej”. W wezwaniach do publicznej prenumeraty $\mathrm{w}$ celu finansowania odkrywców i w retoryce biuletynów towarzystw geograficznych figura geografa zaczęła zlewać się z figura odkrywcy, a potem handlowca (commerçant):

Cel ustalany przez Towarzystwa Geograficzne polegał na wsparciu odkrywania nieznanych i wciąż rzadko odwiedzanych krajów, by czerpać z bogactwa ich ziemi, a także sprowadzać tam wytwory naszego przemysłu, i jednocześnie rozpowszechniać idee moralne, które wyniosą relatywnie niższe rasy na nasz poziom intelektualny. Jednak by

\footnotetext{
Musimy teraz zrozumieć przewagę, jaką daje nam wiedza geograficzna. Gdy Prusacy wkroczyli na nasze terytorium, panowało powszechne przekonanie, że posiadają oni doskonałe mapy, ponieważ są bardzo staranni w tego rodzaju pracy, ale ich mapy mogły być, i w istocie były, jedynie kopią naszych własnych map z drobnymi poprawkami. Ich przewaga polegała na posiadaniu i używaniu tych map, ponieważ przyzwyczajenie do geografii przez pewien czas nauczyło całą kadrę oficerską, jak ważna jest wiedza na temat terenu prowadzonych działań. Większość naszych oficerów, którzy ani w szkole, ani na świecie nie nauczyli się doceniać tej nauki, wyruszało bez map, nie orientując się nawet, że czegoś im brakuje" (Levasseur 1871).
} 
osiagnąć ten cel, młodzież musi mieć apetyt na podróże i eksploracje, jak również posiadać precyzyjną wiedzę geograficzną. Ostatni punkt jest czymś niezbywalnym?

Odkrywca/geografem, czytamy w innym piśmie, jest ten, kto poświęca swoje życie, by dać „świat nauce, a kolonie swemu państwu”. W 1881 roku na łamach Revue de géographie z dumą stwierdzono, że praca czasopisma ułatwiała francuską interwencję w Tunisie (Drapeyron 1881). Nagrody za osiagnięcia oferowane przez towarzystwa geograficzne w przeważającej części odsłaniają tę samą „fantazję o linii prostej”, która naznaczyła transformacje Paryża dokonane dekadę wcześniej przez barona Haussmanna: nowy i otwarty Paryż kapitału finansowego, miasto płynnego ruchu, wewnątrzmiejskich arterii i zuchwałych traktów. Na przykład wyznaczono specjalną nagrodę dla podróżnika, który przejdzie z Algierii do Senegalu przez Timbuktu. Nawiązywała ona do uporczywego marzenia o kolei transsaharyjskiej, która połączyłaby dwie najważniejsze francuskie kolonie, Algierię i Senegal. Jednym z najbardziej ekstrawaganckich projektów dyskutowanych i planowanych w latach siedemdziesiatych było zbudowanie jeziora na środku Sahary ${ }^{10}$. Obrazy z Iluminacji Rimbauda umieszczone obok takich zbiorowych fantazji jak powyższe, traca przypisywana im niemal automatycznie okultystyczną mglistość czy surrealistyczną idiomatyczność.

Inny ciekawy projekt postulował założenie praktycznej wyższej szkoły studiów geograficznych, która miała przeprowadzić naukową kampanię odkrywczą „dookoła świata”. Dla sfinansowania tego przedsięwzięcia jego rzecznicy planowali znaleźć pięćdziesięciu bogatych podróżników, z których każdy wpłaciłby 20 tysięcy franków. Ich nadzieje opierały się na ogromnym sukcesie sztuki bazującej na $W$ osiemdriesiat dni dookoła świata Juliusza Verne’a; sprawa nabrała jeszcze dziwaczniejszego wydźwięku, gdy sam Verne zgodził się stanąc na czele komitetu organizacyjnego.

Jeśli przyjrzymy się bliżej temu szczególnemu projektowi pierwszej zbiorowej podróży dokoła świata, to zobaczymy, że coś się zmieniło. Możemy bowiem rozpoznać w nim całą złożoną dialektykę turystyki masowej: ślady romantycznej ideologii samotnego odkrywcy, który poszukując dziewiczych terytoriów, niezbadanych światów, nagle orientuje się, że zabrał ze sobą cały swój świat na wycieczkę autokarową. Prawdopodobnie nikt lepiej niż Rimbaud nie rozumiał jałowości ucieczki mieszczańskiego turysty od tego, co sam stworzył, jałowości tak dobrze wyrażonej w aforyzmie Weiningera, że „nikt nie może wyjechać ze stacji kolejowej w stronę wolności” (Otto Weininger, cyt. za: Enzensberger 1965, 86). Można to zobaczyć,

\footnotetext{
9 „The Teaching of Geography Given by the Societies of Geography” (1881). Bulletin de Bordeaux 4: $213-$ 214 (niepodpisany).

10 Zabawny opis tego przedsięwzięcia przedstawia Murphy (1948, 70-93). Więcej na ten temat zob. Gros $(1876,220-224)$.
} 
gdy sięgniemy do jednego z ostatnich poematów Rimbauda, Iluminacji zatytułowanej „Wieczór historii”.

En quelque soir, par exemple, que se trouve le touriste naif, retiré de nos horreurs économiques, la main d'un maitre anime le clavecin des prés; on joue aux cartes au fond de l'étang, miroir évocateur des reines et des mignonnes, on a les saintes, les voiles, et les fils d'harmonie, et les chromatismes légendaires, sur le couchant.

Il frissonne au passage des chasses et des hordes. La comédie goutte sur les tréteaux de gazon. Et l'embarras des pauvres et des faibles sur ces plans stupides!

À sa vision esclave, - l'Allemagne s'échafaude vers des lunes; les déserts tartares s'éclairent - les révoltes anciennes grouillent dans le centre du Céleste Empire, par les escaliers et les fauteuils de rocs - un petit monde blême et plat, Afrique et Occidents, va s'édifier. Puis un ballet de mers et de nuits connues, une chimie sans valeur, et des mélodies impossibles.

La même magie bourgeoise à tous les points où la malle nous déposera! Le plus élémentaire physicien sent qu'il n'est plus possible de se soumettre à cette atmosphère personnelle, brume de remords physiques, dont la constatation est déjà une affliction.

Non ! - Le moment de l'étuve, des mers enlevées, des embrasements souterrains, de la planète emportée, et des exterminations conséquentes, certitudes si peu malignement indiquées dans la Bible et par les Nornes et qu'il sera donné à l'être sérieux de surveiller. Cepend ant ce ne sera point un effet de légende!

[W jakiś wieczór, przydarzający się na przykład prostodusznemu turyście, oddalonemu od naszych ekonomicznych okropności, mistrzowska ręka ożywia klawesyn łąk; grają w karty na dnie jeziora, lustra przywołującego królowe i faworyty; widać święte i żagle, synów harmonii, legendarne chromatyzmy na niebie o zachodzie.

Drży, gdy przejeżdżają w galopie pogonie myśliwskie i hordy. Komedia skrapia estrady trawnika. I tłum ubogich i słabych na tych równinach głupoty!

W jego zniewolonej wizji - Niemcy spiętrzaja się ku księżycom; zapalają się tatarskie pustynie; dawne rewolty rozniecają się pośrodku Niebiańskiego Cesarstwa Chin; na królewskich schodach i fotelach powstawać będzie mały świat, blady i płaski, Afryka i Kraje Zachodu. Później balet znajomych nocy i mórz, bezwartościowa chemia, niemożliwe melodie.

Ta sama mieszczańska magia we wszystkich miejscach, do których dowiozłaby nas karetka pocztowa! Nawet początkujący fizyk czuje, że niepodobna poddawać się dłużej tej 
samolubnej atmosferze, mgle fizycznych wyrzutów, których samo stwierdzenie jest już nieszczęściem.

Nie! - Ta chwila wrzącej pary, rozstępujących się mórz, podziemnych pożarów, porwanej planety i postępujących eksterminacji, oczywistości tak nieprzewrotnie poświadczonych przez Biblię i Norny, i które istota poważna powinna by mieć na uwadze. - Nie będzie w tym jednak nic legendarnego!]

Przesuwacz „nasze ekonomiczne okropności” ustanawia teraźniejszość jako moment historyczny wiersza; prostoduszny turysta zostaje wskazany konkretnie za sprawą całej wizualnej i teatralnej retoryki - spektaklu - która, wyłączając ostatnią strofę, dominuje w całym utworze: lustra, chromatyzmy, komedia, estrady, „w jego zniewolonej wizji” i tak dalej. Widz w wierszu zostaje „oddalony od naszych ekonomicznych okropności”, jak przystało na turystę, który dla odpoczynku uciekł z pracy; ale w reszcie utworu zanika możliwość takiego oddalenia.

Wkrótce stanie się jasne, że przed zniewoloną wizją turysty odgrywa się cała spektakularna panorama historii światowej. Zużyte sformułowania przewodnika turystycznego rozbrzmiewają na początku strofy, gdzie odradza się scena arystokratyczna czy feudalna: królowe i faworyty, myśliwi i hordy, widać świętych, welony, itd.

Wysyp nazw geograficznych w trzeciej strofie anonsuje zwycięstwo burżuazji: wracamy do aktualnego momentu historycznego wiersza. Rimbaud przedstawia ten triumf jako ruch nie tyle społecznego, co przestrzennego ujednolicenia. Przez chwilę wzrost burżuazji opisuje wertykalna, wznosząca topografia (Niemcy spiętrzają się, pustynie zapalają się, schody itd.), cały ten wysiłek i energia, skierowane ku górze, stygną w przestrzennej płytkości: „mały świat, blady i płaski”, „ta sama mieszczańska magia we wszystkich miejscach, do których dowiozłaby nas karetka pocztowa”, „balet znajomych nocy i mórz”, „bezwartościowa chemia”.

Napięcie w wierszu rozgrywa się pomiędzy czasową jednorodnością, powtórzeniem i zbędnościa ,„jakiegoś wieczoru”, a historyczną pojedynczością obwieszczoną przez tytuł; pomiędzy przestrzenną homogenicznością, „tej samej mieszczańskiej magii w wszystkich miejscach" a konwulsyjnym powstaniem z ostatniej strofy; pomiędzy figura turysty, oderwanego i niewzruszonego obserwatora widowiskowych obrazów (albo krajobrazów) a istota poważną z końca wiersza, która dozna zdarzenia ${ }^{11}$ - wszystko to stanie się widoczne w apokaliptycznym zakończeniu utworu.

\footnotetext{
11 Autorka posługuje się tu nieprzetłumaczalną grą słów pomiędzy rzeczownikami event (zdarzenie) i evening (wieczór), ten drugi bowiem pojawia się w angielskim tytule wiersza Rimbauda - Historic Evening (przyp. tłum.).
} 
To tak, jakby społeczne powstanie, „zdarzenie” zapowiadane przez tytuł, w obliczu monolitycznej siły burżuazyjnego podboju przestrzeni, mogło rozgrywać się jedynie na skalę światowa. Jeśli administracyjna racjonalizacja, całkowita kolonizacja wszystkich społecznych i kulturowych relacji eliminuje możliwość osiagnnięcia wolności, to emancypacyjną dynamikę może uruchomić tylko apokaliptyczne odwrócenie tego losu i kataklizm rozrywający ciągłość historii. Wysadzona ziemia podwaja społeczny antagonizm, który już w poprzedniej strofie stał się „atmosferą”, „mgła” - czyli ma charakter klimatyczny lub geograficzny.

Ostateczny efekt geologicznej katastrofy z ostatnich wersów daje się odczuć tylko wtedy, gdy ponownie przywołamy dialektycznie przeciwstawną reakcję Mallarmégo. Jego odpowiedź (w efekcie równie silnego zderzenia z hegemonią mieszczańskiej płytkości) przybiera formę poetyki aluzji zaprojektowanej tak, by wykluczyć rzeczywistość z powodu jej wulgarności oraz rozerwać wszelkie zewnętrzne punkty odniesienia. Na fetyszyzację tekstu poetyckiego u Mallarmégo, najlepiej wyrażoną w jego słynnym dictum, „Tout, au monde, existe pour aboutir à un livre” („Cały świat istnieje po to, aby zamknąć go w książce”), Rimbaud odpowie w ostatnim wersie Wieczoru historii: „Nie będzie w tym jednak nic legendarnego”. 


\section{Wykaz literatury}

Benjamin, Walter. 2006. „Rozmowy z Brechtem. Notatki svandborskie.” Tłum. Andrzej Kopacki. Literatura na Świecie 5-6.

Broc, Numa. 1974. „L'établissement de la géographie en France; diffusion, institutions, projets (1870-1890)." Annales de géographie 83-459 (September-October): 545-568.

Depping, Guillaume. 1881. „Le Mouvement géographique.” Journal officiel de la République française 1.

Drapeyron, Ludovic. 1881. „Le But, la methode et l'oeuvre de la Revue de geographie.” Revue de géographie 9: 1-8.

Eisensweig, Uri. 1980. Territoires occupés de l'imaginaire juif: Essai sur l'espace sioniste. Paris: Christian Bourgoi.

Enzensberger, Hans. 1965. „Une théorie du tourisme.” W Culture ou mise en condition? Tłum. Bernard Lortholary. Paris: Julliard.

Giblin, Beatrice. 1978. „Le Paysage, le terrain et les géographes.” Hérodote 9: 74-89.

Gros, Jules. 1876. „La Mer Saharienne et le Capitaine Roudaire.” L'Exploration: Journal des conquêtes de la civilisation sur tous les points du globe 1: 220-224.

Hudson, Brian. 1977. „The New Geography and the New Imperialism: 1870-1918.” Antipode 9-2 (September): 12-19.

Jameson, Fredric. 1984. „Rimbaud and the Spatial Text.” W Re-writing Literary History, red. Tak-Wai Wong i M. Ackbar Abbas. Hong Kong: Hong Kong University Press, 66-93.

Koninck, Rodolphe de. 1984. „La Géographie critique.” W Les Concepts de la Géographie bumaine, red. Antoine Bailly. Paris: Masson, 121-132.

Lacoste, Yves. 1979. „A bas Vidal... Viva Vidal !” Hérodote 16: 68-81.

Lacoste, Yves. 1982. La géographie, ça sert, d'abord, à faire la guerre. Paris: Maspero.

Levasseur, Emile. 1871. „L'Etude et l'enseignement de la géographie.” Séances et travaux de l'Académie des sciences morales et politiques 96.

de Lisle, Charles-Marie Leconte. 1978. Oeuvres diverses, tom. 4. Paris: Société d'édition.

McKay, Vernon. 1943. „Colonialism in the French Geographical Movement 1871-1881.” Geographical Review 33-2 (April): 214-232.

Murphy, Agnes. 1948. The Ideology of French Imperialism. Washington: Catholic University.

Picard, Ernest. 1877. Revue de géographie 1 (January-June): 1.

Reclus, Élisée. 1897. „Préface.” W F. Domela Nieuwenhuis, Le Socialisme en danger. Paris: Stock.

Reclus, Élisée. 1911. Correspondance, tom. 2. Paris: Schleicher.

Reclus, Élisée. 1982. L'Homme et la Terre. Paris: Maspero.

Rimbaud, Arthur. 1993. Wiersze: Sezon w piekle; Iluminacje; Listy, oprac. Artur Międzyrzecki. Kraków: Wydawnictwo Literackie

Santos, Milton. 1984. Pour une géographie nouvelle. Paris: Publisud.

„The Teaching of Geography Given by the Societies of Geography”. (1881). Bulletin de Bordeaux 4: 213-214.

Vermersch, Eugène. 187?. Les Hommes du jour. Paris: G. Towne. 
Kristin Ross - profesorka literatury porównawczej na New York University, zajmująca się francuską kulturą oraz literaturą XIX i XX wieku. Autorka licznych książek, w tym Fast Cars, Clean Bodies: Decolonization and the Reordering of French Culture, May '68 and its Afterlives oraz Communal Luxury.

\section{DANE ADRESOWE:}

Department of Comparative Literature NYU

19 University Place,

3 Fl New York, 10003

EMAIL: kr1@nyu.edu

CYTOWANIE: Ross, Kristin. 2017. „Rimbaud i historia przestrzenna.” Praktyka Teoretyczna 1(23): 215-236.

DOI: $10.14746 /$ prt.2017.1.8

\section{AUTHOR: Kristin Ross}

TITLE: Rimbaud and Spatial History

ABSTRACT: This article is a modified version of a chapter from Kristin Ross's The Emergence of Social Space. Rimband and Paris Commune. Here the author develops three parallel stories examining how conflicts make an imprint on literature and politics and perpetuate the emergence of scientific geography at the end of the 19th century. Although the terms of those conflicts were diverse, they converged upon a concern with the construction of social space. As Ross argues, the ideological notion of space (as something which passively awaits to be conquered) unfolded in parallel among anti-commune politicians, elitist Parnassian poets and the forefathers of French academic geography. Conversely, Rimbaud (along with such radicals as Vermersch and Reclus) outlined a concept of space resistant to competition, hierarchy or the homogenization of reality characteristic for capitalist colonialism.

KEYWORDS: political geography, Paris Commune, anarchism, poetry, colonialism 